Marquette University

e-Publications@Marquette

$1-1-2001$

\title{
The Use of Marketing Knowledge in Formulating and Enforcing Consumer Protection Policy
}

J. Craig Andrews

Marquette University, craig.andrews@marquette.edu

Published version. "The Use of Marketing Knowledge in Formulating and Enforcing Consumer Protection Policy" in The Handbook of Marketing and Society. Eds. Paul N. Bloom and Gregory Thomas Gundlach. Thousand Oaks CA: Sage Publications Inc., 2001: 1-33. Publisher link. (C) 2001 Sage Publications. Used with permission. 


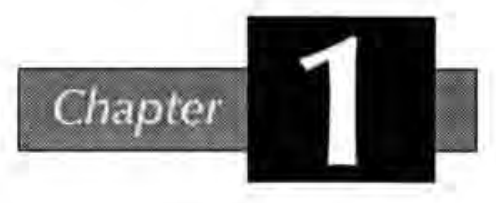

\section{The Use of Marketing Knowledge in Formulating and Enforcing Consumer Protection Policy}

\section{J. Craig Andrews}

The purpose of this first chapter of the handbook is to discuss how the findings and approaches offered by the marketing discipline are used in consumer protection policy. Thus, the link between marketing knowledge and public policy decisions is examined as it pertains to consumer protection, and as depicted in this handbook's model of the paths through which marketing affects societal wefare (see pag xv). The focus of this discussion is on the Federal Trade Commission (FTC), the primary federal regulatory agency of business in the United States. However, other agencies involved in consumer protection at the federal level are mentioned as well (e.g., Food and Drug Administration [FDA]).

As it has been so aptly described in the past, "marketers should recognize that public policy will continue to be created, with or without their research" (Wilkie and Gardner 1974, p. 38). No doubt, our work is appreciated and integrated into many public policy decisions. However, it is in our best interest to examine more completely how our discipline's research is used (and can be used) in the formulation, enforcement, and evaluation of public policy. In this regard, this chapter offers two separate frameworks detailing the use of marketing knowledge in the formulation and enforcement of public policy decisions. Then, examples of spe-

AUTHOR'S NOTE: The author gratefully acknowledges the assistance of Lee Peeler, associate director; Anne Maher, assistant director; and the staff in the Division of Advertising Practices at the Federal Trade Commission. He also appreciates the helpful comments of Ross Petty, Terry Shimp, Judy Wilkenfeld, two anonymous reviewers, and the two editors on a previous version of this chapter. 
cific research applications (e.g., nutrition labeling and claims, deceptive advertising and remedies) and theoretical frameworks are cited in which our discipline has contributed to consumer protection missions of agencies. Finally, cautions and suggestions in conducting research in marketing and public policy are examined, and future research opportunities are explored.

\section{History of Marketing Knowledge Use in Consumer Protection Policy}

\section{The Early Years: 1970 s}

The history of contributions from the marketing discipline to public policy spans the entire 20th century (cf. Hollander, Keep, and Dickinson 1999; Wilkie and Moore 1999). However, many of the contributions from the marketing field to public policy have taken place within the past three decades and focus on work with the FTC (for a history of the FTC, see Zuckerman 1990). Three focal areas for FTC decisions on consumer protection matters are policy planning, enforcement, and evaluation (Bernhardt and Stiff 1981; Jones and Silverman 1973; Wilkie and Gardner 1974). In 1969, the Nader and American Bar Association reports on the effectiveness of the FTC's consumer protection mission cited weaknesses in these basic decision areas. Specifically, case selection on trivial problems, time delays in investigation and enforcement, and ineffective remedies were mentioned (cf. Wilkie and Gardner 1974). The establishment of the Office of Policy Planning and Evaluation and a more streamlined information system were used to help with these concerns. Commissioner Mary Gardiner Jones, among others, believed that input from marketing academics could help in the areas of planning, enforcement, and evaluation (Jones 1990; Jones and Silverman 1973). So in 1971, Commissioner Jones initiated the process by which many marketing academics served at the FTC in roles such as advising commissioners and bureau directors, assisting attorneys with cases, conducting planning and evaluation studies, providing economic analyses of cases, and serving as experts in rule making (cf. Murphy 1990). During the early years, contributions of marketing academics to planning and formulation of policy were evident in aiding the efficient allocation of limited resources (e.g., rule making, guides, information disclosure programs). For example, marketing academics were instrumental in formulating the FTC's (1979) policy on consumer information remedies. However, formal input into the planning function declined during the 1980s when the separately formed Office of Policy Planning was disbanded (Maronick 1990).

Although contributions from marketing academics to the enforcement mission of the FTC have continued since the early days of participation, it has not always been an easy task to communicate such contributions. As indicated by Jones and Silverman (1973), barriers exist limiting the contributions of research to ongoing judicial and legal proceedings. Such barriers include research that is viewed as offering tentative and inconclusive results, exactly the opposite of 
what is preferable in a legal setting. Moreover, during this time, copy test research used in ad deception and unfairness cases sometimes was described as the "battle of the tests" pitting researchers against one another in court (Jones and Silverman 1973; more recently, see Jacoby and Szybillo 1995; Stewart 1995; and Sudman 1995 regarding the Kraft Inc. 1991 case). Others described the inability of researchers to adequately explain to presiding officers, administrative law judges (ALJs), and attorneys in proceedings exactly what was conducted in the research and why it should be given weight in court (Bernhardt and Stiff 1981). Improvements in research methodology were needed to avoid criticisms such as small samples, inappropriate selection, and weak controls. Reviews of FTC and Lanham Act deceptive ad cases showed that many of these methodological problems persisted through the 1980s (cf. Preston 1987, 1992). This was especially important in Lanham Act cases between competitors involving implied claims in which extrinsic evidence of deception is required (Cohen 1995).

However, in reviews of early contributions to the FTC's mission, both Bernhardt and Stiff (1981) and Wilkie and Gardner (1974) indicated that public policy officials shared a sincere interest in contributions from marketing and consumer research. Consumer protection activities such as case and area selection, rule making, case investigations, fact finding, remedy alternatives, and evaluation of remedies all were enhanced as a result of input from marketing academics. As suggested by Bernhardt and Stiff (1981), discussions among FTC staff now included methodological issues such as statistical significance, sample size requirements and procedures, and multivariate analysis techniques. However, formidable gaps existed in knowledge, communication, and interpretation of the marketing evidence between those in the marketing discipline and public policy decision makers. Wilkie and Gardner (1974) cited misconceptions of consumers operating under the "economic man" assumption, a lack of concern for consumer psychological needs, the assumption that "more information is better," little attention to the quality of message content, and the assumption that all information is processed the same by all consumers, among others. Other constraints, such as the limited time necessary to conduct investigations, little training in the legal and economics professions in behavioral sciences, and the struggle between internal and external validity of research, contributed to the gap between the marketing profession and public policy decisions during the early years.

Perhaps the most important lesson from such misinterpretations on the part of all parties is the need for a better understanding of the different disciplines involved in public policy decisions. For example, in the examination of labeling research, Mazis (1980) proposed four different perspectives on the issue, with each perspective frequently studying the topic from its own myopic viewpoint. The psychological perspective stressed maximizing labeling benefits by improving the consumer impact (e.g., comprehension) of the information presented. The economic perspective focused on minimizing costs to sellers in the marketplace, whereas the legal perspective was concerned with cost minimization in litigation and violation of law. Finally, the consumerist perspective focused on the benefits of providing as much information to consumers as possible (e.g., enhancing consumers" "right to know"). Obviously, a better understanding and 
integration of these different perspectives would serve to improve public policy decisions.

\section{A Decade of Change: 1980 s}

Although the number of enforcement actions declined during the $1980 \mathrm{~s}$, it was apparent that the role of marketing and consumer research had been elevated in such actions (Ford and Calfee 1986; Petty 1992, p. 58). For example, although not required per se in the evaluation of deceptive ad cases, the use of extrinsic evidence (e.g., copy tests) became increasingly important in FTC cases. In Thompson Medical Company Inc. (1984), the FTC indicated, "The evidence we prefer to use and to which we give great weight is direct evidence of what consumers actually thought upon reading the advertisement in question" (p. 789). Moreover, former FTC commissioner Jones (1990), suggested many additional opportunities for marketing academics in this new environment, including the need for input on information disclosures, consumer vulnerability to ad deception, and effective methods of relief. However, she recommended that the Commission take a further step by formally recognizing our discipline through the establishment of a Bureau of Consumer Behavior Research. Other ideas offered for increasing involvement of our field in public policy decisions included inviting staff and commissioners to conferences, sending in copies of research articles, and participating in FTC hearings.

A review by Maronick (1990) provided direct insight into the role of consumer research at the FTC during the 1980s. Major changes cited by Maronick included the disbanding of the Office of Policy Planning and a reduced emphasis on trade regulation rules (TRRs). The political environment, the need for explicit cost-benefit analysis, scarce funding, and evaluation problems in longterm tracking all contributed to a decline in TRRs and, therefore, resulted in less activity for the Office of Impact Evaluation in baseline and follow-up studies of TRRs. An increased reliance on an evaluation committee in the Bureau of Consumer Protection occurred in which the committee enforced its "100-hour rule" requiring approval for cases before they moved to a full-phase status (Maronick 1990). The Commission also relied more on "mini-studies" during this period in deceptive ad investigations. Such copy tests included, on average, only 20 to 40 consumers in a single location and were substantially less expensive than normal copy test projects. The advantage was that such a test gave a quick and inexpensive read for the staff on potential cases. However, this approach was open to criticism regarding the generalizability of the findings and offered potential problems if introduced into case proceedings.

\section{Renewed Activity: 1990s and Beyond}

The 1990s showed an increase in enforcement actions, policy statements, and guides (although not rules) at the Commission. In terms of the marketing academic roles at the FTC described by Murphy (1990), contributions during the 
1990s were primarily in assisting attorneys with cases and in administering contract research. Other roles included advising commissioners and bureau directors (sometimes through staff and advisers) as well as providing assistance with rules, guides, policy statements, reports, and hearings, Other activities popular during the $1970 \mathrm{~s}$ at the bureau and commission level, such as conducting planning studies and participating in policy review sessions, were not part of the everyday routine of academics at the Commission during the $1990 \mathrm{~s}$. However, due to the specialized and decentralized structure of the FTC at this time, opinions of marketing academics regarding planning and policy were sought at the division level (e.g., Division of Ad Practices), where initial investigations are launched. The reliance on economic analysis and input continued as applied to rules, guides, and policy statements (e.g., environmental marketing guides [FTC 1992]). However, the following rules, guides, policy statements, reports, and associated hearings all received input and review by specialists in the marketing discipline: environmental marketing guides (FTC 1992 [and 1996 revision]), "900 number" disclosure rule (FTC 1993), enforcement policy statement on food advertising (FTC 1994), telemarketing sales rule (FTC 1995b), dietary supplement advertising guides (FTC 1998a), and privacy on-line report to Congress (FTC 1998d). In addition, the marketing discipline played an important part in providing consumer research for the FDA's (1996) regulations restricting the sale and distribution of cigarettes to children and adolescents, for everyday activities at the FDA's Center for Food Science and Nutrition, and for the FDA's over-the-counter (OTC) drug advertising and labeling. At the FTC, the marketing field played a valuable role in providing copy test evidence and in expert witness testimony in the Stouffer Foods Corporation (1994) (see review by Andrews and Maronick 1995) and Novartis Corporation ("Doan's Pills") (1999) trials. In turn, key public policy officials actively solicited the help of the marketing profession with calls for research on a wide variety of consumer protection topics (cf. Bernstein 1996; Schultz 1996; Starek 1993; Steiger 1994). Thus, the 1990 s saw a resurgence of activity at the FTC as well as in the solicitation and use of marketing knowledge in consumer protection policy and decisions.

On the academic side, the marketing and public policy discipline flourished during the 1990s, with important contributions from the Journal of Public Policy \& Marketing (JPP\&M), the continued success of the annual Marketing and Public Policy Conference, and the start of the Marketing and Society special interest group of the American Marketing Association (Mazis 1997). A mentor program currently matches scholars in the marketing and public policy field with doctoral students and new Ph.D.s expressing an interest in the discipline. Recent texts on legal decision making in marketing (Cohen 1995) and edited volumes addressing research on consumer issues in public policy (Bloom and Gundlach 2000; Hill 1996; Macklin and Carlson 1999) are valued resources for our profession. Finally, a series of retrospective articles in $J P P \& M$ described historical viewpoints of six leading marketing and public policy scholars (Andreasen 1997; Bloom 1997; Greyser 1997; Kinnear 1997, Mazis 1997; Wilkie 1997) and represent important reading for anyone considering a contribution to public policy. 


\section{Marketing Knowledge and the Formulation} of Consumer Protection Policy

\section{Knowledge Development in Policy Formulation}

As indicated by Hunt $(1978,1991)$, the primary directive for scholarly research in marketing and other disciplines is to seek knowledge. Knowledge must be "intersubjectively certifiable and capable of describing, explaining, and predicting phenomena" (Hunt 1978, p, 109). Possible audiences for such marketing knowledge may be marketing managers, educators and scholars, public policy officials, special interest groups, and consumers (Monroe et al. 1986; Shimp 1994). Contributions to knowledge can be classified as theoretical, empirical, methodological, or critical and can be diffused in a multitude of ways (e.g., academic journals, fellow academics, texts, students, seminars, consulting, expert witnessing [Shimp 1994]). Thus, there are many routes of relevance for marketing knowledge and for its application to public policy. The ultimate contribution of such knowledge will depend on the degree to which the research is representative of the issue that is being studied (Shimp 1994).

\section{A Framework for the Formulation of Consumer Protection Policy}

The following framework displays a variety of relevant routes for marketing knowledge in the formulation of consumer protection policy. It is based on direct experience of the author in serving at the FTC and on interviews with FTC personnel. It also uses the author's experiences with the FDA in its use of marketing knowledge in rule-making procedures. In comparison to in-house initiatives at the FTC during the late 1970s (e.g., the children's advertising rule), the starting point during recent years often has been a "change agent" (e.g., Congress, Center for Science in the Public Interest [CSPI], Center for Media Education, National Association of Attorneys General) that has precipitated action. For example, both the "900 number rule" (FTC 1993) and the telemarketing sales rule (FTC 1995b) were motivated by legislative acts of Congress directing FTC involvement. Similarly, although FTC hearings and workshops on privacy occurred since 1995, the FTC's (1998d) privacy on-line report to Congress responded to inquiries by Senator McCain and Representative Bliley for their respective congressional commerce committees. However, other consumer and industry groups (e.g., Children's Advertising Review Unit, Direct Marketing Association, Center for Media Education) played instrumental roles with respect to the formulation of proposed rules for notice, choice, access, and security of information collected from children over the Internet (cf. the FTC's [1999b] children's on-line privacy protection rule). In a similar fashion, the FTC's (1994) operating policy statement on food advertising was influenced by the passage of the Nutritional Labeling and Education Act (1990), maintaining consistency with the FDA's (1993) nutritional labeling regulations and addressing enforcement criticisms suggested by the CSPI's (1994) Food Advertising 
Chaos: The Case for Reform. In the case of the environmental marketing guides, the FTC (1992) received petitions from industry members and trade associations to issue guides. Also, a task force of state attorneys general strongly recommended that uniform environmental marketing standards be issued at the federal level. As a final example, the Clinton administration and public health community represented important change agents in supporting the issuance of the FDA's (1996) proposed tobacco regulations. Although the Supreme Court ruled recently that the FDA lacked the authority to regulate tobacco at this time (FDA v. Brown \& Williamson Tobacco Corporation 2000), this does not necessarily preclude Congress from taking action in the future.

Trade regulation rules, guides, and operating policy statements at the FTC usually are the result of industry-wide problems that would make the traditional case-by-case enforcement approach inefficient. As indicated in Figure 1.1, prior legal precedent, case law, and jurisdiction in the formulation of such rules, guides, and policy statements provide the framework for FTC staff and commission action. For example, in the enforcement policy statement on food advertising (FTC 1994), the FTC, FDA, and U.S. Department of Agriculture all share jurisdiction in the regulation of food product claims. However, a 1954 memorandum of understanding between the FDA and FTC assigns the FTC the responsibility for regulating food advertising, whereas the FDA bas taken primary responsibility (except for meat and poultry products) in regulating food labeling. In addition, the FTC's legal authority in regulating the practice in question usually is outlined in the rule, guide, or policy statement. In the case of food ad claims, the FTC has statutory authority to prohibit deceptive acts or practices under Section 5 of the FTC Act. The FTC's deception policy statement (reprinted in Cliffdale Associates Inc. 1984, pp. 110, 176) and advertising substantiation policy (reprinted in Thompson Medical 1984, pp. 648, 839) normally are cited to set the stage for regulation or policy with respect to deceptive ad claims in a given industry. Although not as common, the FTC's unfairness policy (FTC Act Amendments 1994) can be applied as support for rules, guides, or operating policy if unfairness exists (Preston 1995: Simonson 1995).

\section{Direct Contributions to Policy Formation}

It is within this context that marketing knowledge and information provided by marketing consultants is valued and used in the formation of rules, guides, and policy statements (Figure 1.I). At times, this information is directly incorporated into the formal release statements. For example, in the case of the FTC's (1993) "900 number rule," the Commission wished to allow more flexibility in the size and presence of sweepstakes disclosures. Direct evidence was cited (FTC 1993, 132 ff.), based on research by Bhalla and Lastovicka (1984) and Petty and Cacioppo (1986), to indicate that disclosure size variability might be desirable in some cases to reduce "wear-out" and enhance ad noticeability. Similarly, marketing and advertising research (Barlow and Wogalter 1993; Hoy and Stankey 1993; Murray, Manrai, and Manrai 1993) is cited directly in the recent policy statement proposal regarding the applicability of rules and guides to elec- 


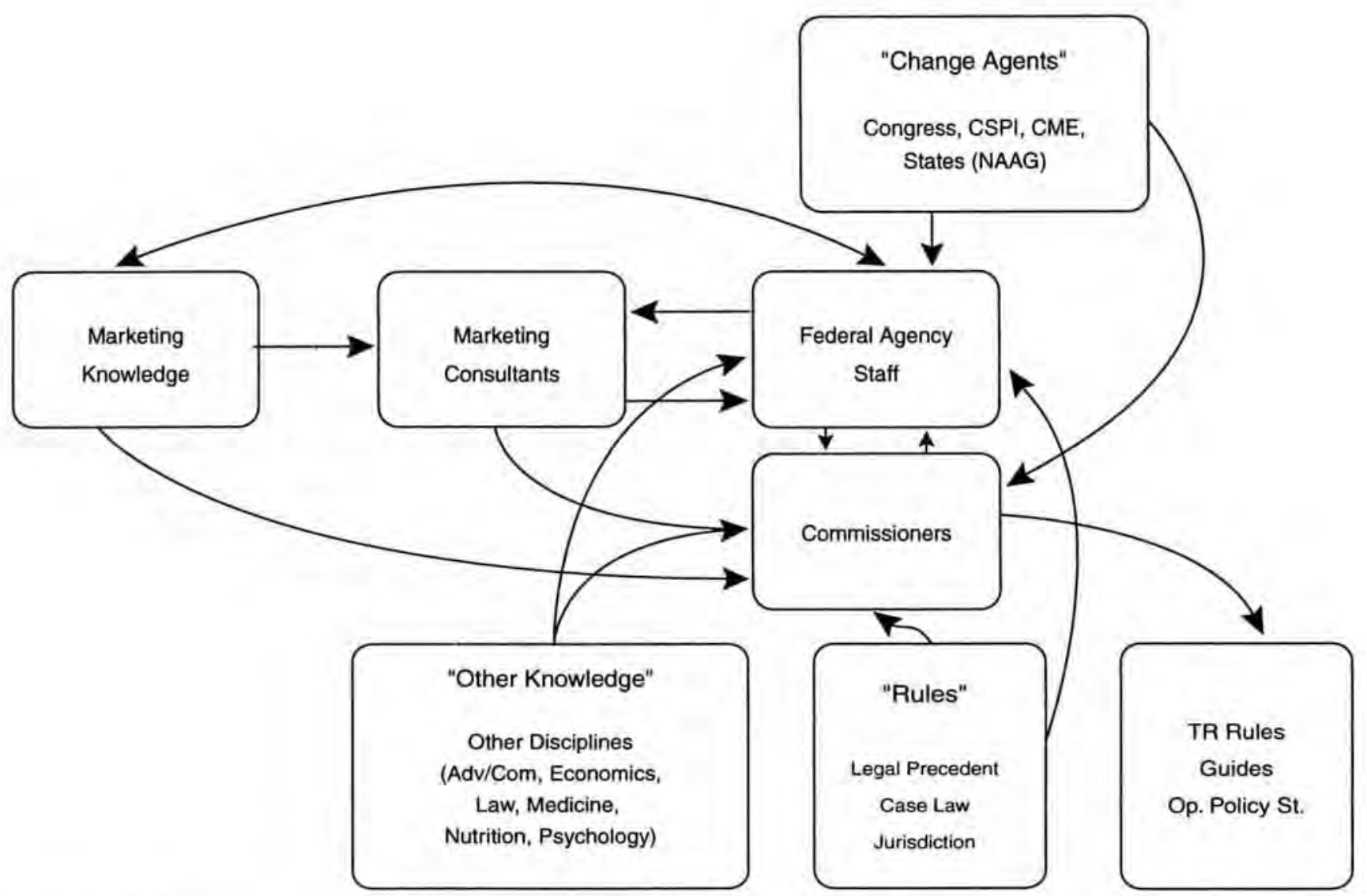

Figure 1.1. Marketing Knowledge and the Formulation of Consumer Protection Policy

NOTE: $\mathrm{CME}=\mathrm{Center}$ for Media Education; $\mathrm{NAAG}=$ National Association of Attorneys General: $\mathrm{Adv} / \mathrm{Com}=$ advertising and communications; $\mathrm{TR}$ Rules $=$ trade regulation rules; Op. Policy $\mathrm{St}$. = operating policy statements. 
tronic media (FTC 1998c, p. 28003) to indicate a preference for the simultaneous use of visual and audio modes in disclosures. An examination of the FTC's (1998d) privacy on-line report to Congress reveals substantial reliance on marketing and demographic studies in explaining the extent of Internet use. Finally, the FDA's (1996) tobacco rules to protect children and adolescents contained numerous cites to marketing, advertising, and social psychology research. For example, research by Lutz and Lutz (1977) was offered on the role of ad imagery (FDA 1996, p. 44467); Petty and Cacioppo's (1986) elaboration likelihood model was examined in the context of peripheral route imagery (FDA 1996, p. 44468); and Lavidge and Steiner (1961), McGuire (1962), and Pechmann and Ratneshwar (1994) were cited with respect to ad persuasion and belief processes. Different positions on the effectiveness of cigarette ad bans were offered directly in the tobacco rule (Boddewyn 1994; Cohen 1990).

\section{Indirect Contributions to Policy Formation}

Because research studies often are not available at the time of the issuance of rules or guides on emerging public policy issues, marketing knowledge and information from marketing consultants frequently plays an indirect role in the formulation of consumer protection policy. For example, the FTC usually posts a 60 -day request for comments on proposed rules or guides. In-house (and sometimes external) marketing consultants will review the proposal. Next, hearings and workshops often are planned, with a 60-day period offered to indicate a willingness to participate. Quite often, the consultants will be helpful in suggesting and evaluating proposed questions for the workshops or hearings. In the case of a recent proposed workshop on the interpretation of FTC rules and guides for electronic media (FTC 1999a), a series of questions for researchers were offered in the interpretation of the "clear and conspicuous standard" for disclosures as applied in electronic media. Alternatively, marketing knowledge may have an impact in hearings and workshops conducted prior to the issuance of the rules or guides. For example, extensive hearings were held in 1995 in conjunction with the planned revision of the FTC (1992) environmental marketing guides. At the hearings, consumer researchers provided helpful evidence in the form of tracking studies on environmental claim use across product categories and geographical areas (Mayer et al. 1995).

Calls for consumer research by public policy officials often occur in conjunction with the issuance of rules and guides. As an example of this, the question of whether consumers will generalize from nutrient and health claims in advertising given the omission of an important negative nutrient was raised on several occasions (e.g., Bernstein 1996; Starek 1993). If such generalizations occurred, the FTC then raised the question, "What kind of disclosure best conveys the presence and significance of the risk-increasing nutrient-a numerical disclosure of the percent[age] of daily value of fat contained in each serving, a concise verbalization, or some other disclosure format?" (Bernstein 1996, p. 313). To answer this question, a series of studies were conducted by researchers in marketing and economics (cf. Andrews, Netemeyer, and Burton 1998; FTC 1998b). 
Evidence from one study shows that consumers do indeed generalize from such ad claims, although this generalization is dependent on the product category, ad claim specificity, consumer nutrition knowledge, and disclosure type used (Andrews, Netemeyer, and Burton 1998). In other instances, marketing consultants (and their knowledge) have had an impact in discussions during joint meetings with staff attorneys and industry and trade representatives with respect to details of trade rules and guides. Similarly, marketing consultants serve an important function in the coordination and implementation of certain rules and guides (e.g., environmental marketing) with other federal agencies and in discussions with consumer protection personnel from other countries (e.g., Canada, Russia).

\section{Marketing Knowledge and the Enforcement of Consumer Protection Policy}

\section{A Framework for the Use of Marketing Knowledge in the Ad Enforcement Process}

\section{Introductory Stages}

Based on direct experiences and observations by the author, as well as input from staff attorneys, Figure 1.2 offers insight as to how marketing knowledge is used in the advertising enforcement process at the FTC. The figure focuses primarily on contributions at the division level (i.e., Division of Ad Practices) and on external influences in the process, as other frameworks have been offered tracing the internal steps of FTC staff, commissioners, and ALJs in the case process (cf. Wilkie, McNeil, and Mazis 1984,p. 18). The starting point in Figure 1.2 is similar to the notion of change agents in Figure 1.1; however, in this case, the petitions to the FTC from complaint sources reflect the narrower focus on a specific, potential violator. For example, in "Campbell Soup Company" (1992), complaints to the FTC about the company's "heart healthy" campaign surfaced from the American Heart Association and the CSPI due to the omission of relatively high sodium levels in the advertised soup products. Alternatively, a refusal to abide by self-regulatory bodies, such as the National Advertising Review Board, might indicate the need for action at the federal level (e.g., Eggland's Best Inc. 1994). On occasion, actions are initiated due to order violations found by the FTC's Division of Enforcement (e.g., Hasbro Inc. 1993, 1996). The state attorneys general and citizen complaints also represent important sources for beginning possible enforcement actions. In 1997, the FTC joined with many state attorneys general offices in conducting sweeps and bringing actions against fraudulent providers of promotional and telemarketing services. Contrary to popular belief, however, the FTC does not have the resources to monitor all ads appearing across print, broadcast, and electronic media. Thus, a reliance on, and a close relationship with, external complaint sources is important in tracking practices that are potentially deceptive or unfair. 


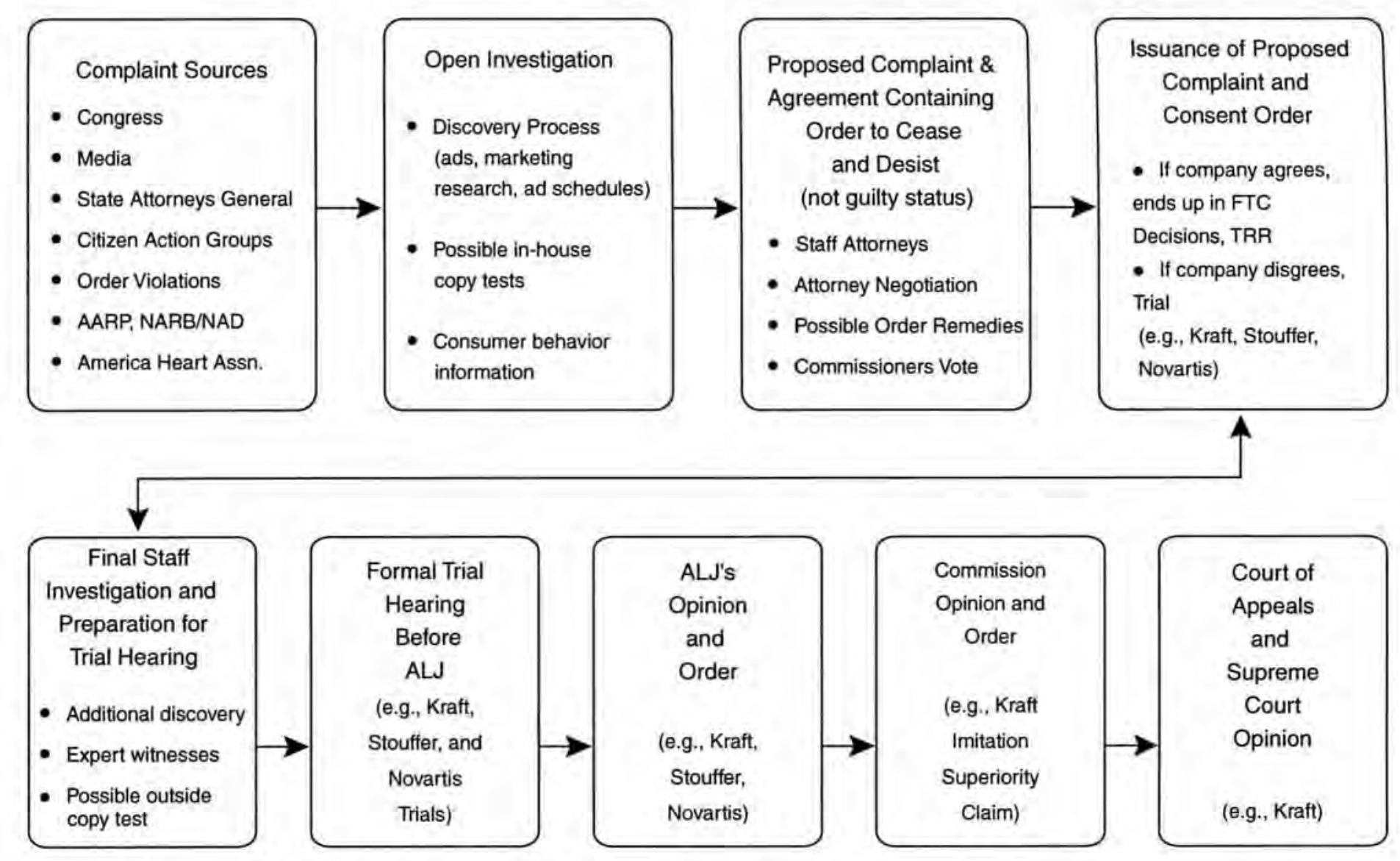

Figure 1.2. Marketing Knowledge and the Advertising Enforcement Process 
The next step in Figure 1.2 is that an investigation is opened if the case is within the FTC's jurisdiction under the FTC Act, involves interstate commerce and the public interest, and deserves allocation of the Commission's limited resources. The first stage in the discovery process of the investigation is for the staff attorneys assigned to the case to send an access letter to the company requesting all materials pertaining to the campaign in question (e.g., ads disseminated, marketing research, ad schedules). An investigation of these materials is important in establishing whether the claims were made and in bringing forth any intent to make the claims by the company (see introductions to Kraft 1991; Novartis 1999; Stouffer Foods I994). (Note that intent is not required but represents a presumption of materiality if found [see deception policy appended to Cliffdale Associates 1984, pp. 182-183].) Next, an in-house copy test or other preliminary marketing or consumer behavior evidence may be brought to bear on the case. Normally, in-house marketing consultants conduct such tests, although many outside marketing consultants have been valuable in this capacity. Such an analysis is important to screen out potentially weak cases that might absorb Commission resources. If a copy test is proposed, then the research challenge is to construct the most appropriate test possible given limited resources at this juncture (see "mini-studies" in Maronick 1990).

Following initial evidence from the discovery process, in-house copy tests, and consumer research in general, a decision may be made by the staff attorneys to recommend to the bureau director that a proposed complaint be developed (Figure 1.2). The staff economists are likely to provide important evidence and analysis at this stage as well. The eventual complaint that is developed is accompanied by an order, often to cease and desist from the practice in question. The breadth of product coverage in the order usually is determined by the nature of the violation and is open to negotiation between the staff attorneys and the company at this stage. Depending on the nature of the offense, the order may contain possible remedies such as triggered disclosures, corrective advertising, and consumer redress (for remedy effectiveness issues, see Wilkie, McNeil, and Mazis 1984). At this point, input from marketing consultants, armed with knowledge on the planning, development, and implementation of remedies, can be valuable in determining the success of the enforcement action. At times, staff attorneys may seek an injunction in federal court at this stage (e.g., to freeze assets of a firm involved in fraud or revoke an Internet domain name for a fraudulent Internet advertiser). The commissioners then will vote on the complaint and order provisions (also known as a consent agreement). If the company agrees to the consent agreement, they retain a "not guilty status" yet must abide by the order provisions. The result then is published in FTC Decisions and the Trade Regulation Reporter. However, if the company disagrees, then the case goes to trial before an FTC Administrative Law Judge (ALJ) (see, e.g., Kraft 1991; Novartis 1999; Stouffer Foods 1994).

\section{Preparation for Trial}

As indicated in Figure 1.2, if the company elects to go to trial, then the FTC engages in final staff investigation and preparation for the trial hearing. This entails additional discovery and the collection of extrinsic evidence for the trial. 
Although such evidence is not required per se, it is nonetheless considered and given substantial weight in cases involving potentially deceptive implied claims (Thompson Medical 1984, p. 789). Extrinsic evidence can include expert witness testimony, common use of terms, generally accepted principles in marketing research, and methodologically sound consumer research studies (e.g., ad copy tests) (Kraft 1991, pp. 121-122). For example, in the Stouffer Foods (1994) trial before the ALJ, the complaint counsel (i.e., FTC staff attorneys) relied on an outside copy test, expert testimony on consumer behavior principles (e.g., priming, relational processing of ads), and expert review of disclosure research. The defendant used an outside copy test and expert testimony. Thus, because most cases moving to trial involve implied claims in question, the role of extrinsic evidence and the use of marketing knowledge have become increasingly important in FTC cases over the years.

Following the trial before the ALJ and the ALJ's opinion and order, the Commission will issue its separate opinion and order based on its expertise and evidence presented at the trial (Figure 1.2). At times, the commissioners might disagree with part or all of the ALJ's ruling, as happened in the Kraft (1991) case. In Kraft, although the commissioners agreed with most of the ALJ's decision (e.g., involving the challenged "milk equivalency" claim), they made two major changes in their ruling. First, the commissioners did not see evidence implicating Kraft's "class picture/5-ounce" ads as making the challenged "imitation superiority" claim. However, they broadened their order to include a wider range of cheese products. Kraft appealed the decision, but the FTC decision was upheld in the 7 th Circuit (Kraft v. FTC 1992). On further appeal, the Supreme Court refused to hear the case, leaving the 7 th Circuit decision to stand.

\section{Contributions to Consumer Protection Policy}

\section{Application Areas}

Although a wide variety of specific contributions to consumer protection policy are mentioned in previous reviews (cf. Andreasen 1997; Andrews 1996; Bloom 1997; Mazis 1997), the purpose of this section is to highlight six important application areas where the collective research from our profession has made a difference. The review of these areas and contributors is not meant to be exhaustive (see, e.g., the past 19 volumes of $J P P \& M$ for more complete coverage); rather, it is intended to provide several examples of research programs that have contributed to consumer protection policy.

\section{Deceptive Advertising, Remedies, and Unfairness}

As indicated in the preceding section, although not required per se, extrinsic evidence is nonetheless considered in the case of potentially deceptive ad claims at the FTC, especially when they are of an implied nature. During recent years, ad copy tests have represented the primary form of extrinsic evidence offered in deceptive ad cases at the Commission and in Lanham Act cases (cf. Cohen 1995; Kraft 1991; Novartis 1999; Stouffer Foods 1994; Thompson Medical 1984). As 
such, an important contribution from the work of Preston $(1987,1992)$ is a historical review and analysis of prior extrinsic evidence including what elements the Commission and courts have given greater weight in the proceedings. (For a thorough review of ad regulation in the European Union [EU] vs. the United States, see Petty 1997. A detailed comparison of Lanham Act vs. FTC cases can be found in Petty 1992.) In the Commission's consideration of extrinsic evidence, adherence to generally accepted principles is perhaps the most important criterion for researchers to remember. These principles evolve from FTC case precedent (see above) and reviews and analysis in marketing and legal research (cf. Andrews and Maronick 1995; Jacoby and Szybillo 1995; Maronick 1991; Morgan 1990; Owen and Plyler 1991; Plevan and Siroky 1991; Preston 1987, 1992; Stewart 1995). Issues such as the universe, sample drawn, method of questioning, experience in design and execution, controls, data collection, and analysis represent fertile ground for challenges in FTC legal proceedings. Although such general standards or principles exist, their operationalization to the case situation often is very different from researcher to researcher.

There are several examples of contributions from the marketing discipline in the direct study of the FTC's deception policy statement (appended to Cliffdale Associates 1984). For example, Ford and Calfee (1986) offered a thorough analysis of the 1983 change in deception policy at the Commission including the likely outcomes of such a change. Others examine the three important elements of deception policy: (1) misleadingness, (2) the reasonable consumer, and (3) materiality. Specifically, the first element in the FTC deception policy concerns whether a representation, omission, or practice is likely to mislead consumers. Examples of such misleadingness include misrepresentations that are contrary to fact and misleading omissions. Effects of misleading advertising and remedies have been analyzed in several consumer research studies, often in an experimental setting (cf. Andrews, Netemeyer, and Burton 1998; Burke et al. 1988; Johar 1995; Olson and Dover 1978; Pechmann 1996; Russo, Metcalf, and Stephens 1981). The second element examines the potentially deceptive practice from the perspective of a consumer acting reasonably under the circumstances (e.g., a member of the target market). Researchers have studied the role of product expertise and involvement levels associated with the reasonable consumer element in deceptive advertising (Laczniak and Grossbart 1990). Finally, the third element in the FTC deception policy requires that the representation, omission, or practice be a "material" one. That is, the issue is whether the act or practice is likely to affect the consumer's conduct or decision regarding the product or service in question. Although materiality often falls under presumptive elements (e.g., health and safety concerns, intent, seller knowledge), considerable debate has ensued regarding this element in deception, especially in conjunction with the challenged "milk equivalency" claim in Kraft (1991; see also Jacoby and Szybillo 1995; Stewart 1995; Sudman 1995).

In addition, the Commission has relied on economic evaluations of deception (Pappalardo 1997). For example, economics of information theory posits that consumers tend to be less skeptical of search claims than of experience claims (i.e., when the product cannot be inspected prior to purchase) and most skeptical of credence claims (i.e., when consumers lack the expertise or time to verify the 
claims) (Ford, Smith, and Swasy 1990; Nelson 1974; Smith 1990). Kraft (1991) and Novartis (1999) are examples of FTC cases for which credence claims are at issue because reasonable consumers lack the ability to evaluate material claims on health and back pain.

As suggested by former Commissoner Jones (1990; Jones and Silverman 1973), perhaps one of the more important contributions from the marketing field is the expertise that is provided on remedies to deceptive practices. A wide variety of remedies are possible as part of deceptive ad orders including affirmative and triggered disclosures (cf. Wilkie 1985), warnings (cf. Stewart and Martin 1994), consumer redress, and corrective advertising (cf. Wilkie, McNeil, and Mazis 1984). The latter remedy, corrective advertising, remains an extremely important tool for the Commission today and recently was applied in the Novartis (1999) case. Researchers working in this area are encouraged to read Wilkie, McNeil, and Mazis (1984) for a thorough review of corrective advertising history and its overall effectiveness.

Legal marketing scholars have examined recent changes in the FTC's unfairness policy that amended the FTC Act in 1994 (Preston 1995; Simonson 1995; for unfairness history, see Cohen 1982). Unfairness elements of (1) substantial injury to consumers that are (2) not reasonably avoidable by consumers themselves and (3) not outweighed by countervailing benefits to consumers or competition have been evaluated by these scholars, as have unfairness application areas (e.g., children, TRRs, substantiation theory) and the likely impact of the 1994 changes. Finally, discussion of the FTC's policy planning protocol for substantiation actions can be found in Cohen (1980).

\section{Tobacco Advertising, Promotion, and Regulation}

A variety of studies in consumer bebavior and economics thoroughly examine the effectiveness of past tobacco regulatory initiatives and the difficulty of measuring cause-and-effect relationships (cf. Calfee 1986; Cohen 1990). Numerous research studies from the medical and advertising professions have studied effects of the "Old Joe the Camel" campaign on children's logo recognition rates, brand recall, preferences, and market share estimates (for a listing of seven of these, see Andrews 1996). Recent testimony before the FTC on the Old Joe campaign has applied important consumer behavior principles in evaluating the impact of the campaign (Cohen 1998). In light of increased litigation and proposed FDA regulations, many states initiated a settlement with the tobacco industry to recoup medical and other costs. Goldberg and Kozlowski (1997) and Petty (1999) provided critical analyses of this 1997 tobacco agreement with the state attorneys general. No doubt, future work will examine other tobacco regulations such as those proposed by the FDA (1996). Recently, consumer research on adolescents has suggested that exposure to anti-smoking ads makes salient prior beliefs about smoking risks and leads to less favorable thoughts about smokers (Pechmann and Ratneshwar 1994). This experimental research also has suggested that exposure to cigarette ads results in more favorable thoughts about smokers. Other recent consumer research has shown the effectiveness of processing interventions in anti-smoking appeals (Keller and Block 1996) and that 
young adult perceptions of addiction and financial risks are directly related to smoking status (Rindfleisch and Crockett 1999). Future research is likely to systematically examine the many existing state anti-smoking campaigns (cf. Pechmann and Goldberg 1998). Finally, several studies have used meta-analyses and market share estimation to examine the overall impact of tobacco advertising (Andrews and Franke 1991; Pollay et al. 1996).

\section{Understanding Children's Advertising and Promotion}

This topic attracted a considerable amount of interest by researchers (and resources at the FTC) during the late 1970s to early 1980s (cf. FTC 1978, 1981). Extensive hearings were held during this time to examine young children's difficulties in understanding and processing televised advertising messages and reactions to promotions. An example of one important contribution at this time is the identification of different processing levels of children (e.g., strategic, cued, limited) varying by age and based on storage and retrieval differences (Roedder 1981). Such research offered clear and specific public policy alternatives (p. 150), although political changes led to the termination of the FTC initiatives (FTC 1981). However, research programs continued, studying questions such as the formulation and use of cognitive defenses to promotion (Brucks, Armstrong, and Goldberg 1988) and adaptive decision making on behalf of children (Gregan-Paxton and Roedder John 1997), Early experimental research included examinations of snack commercials and public service announcements (Goldberg, Gorn, and Gibson 1978) and whether young children understood the selling intent of commercials (Macklin 1985). Recently, Martin (1997) performed a meta-analysis of findings with respect to this latter inquiry. Also, researchers are encouraged to examine new findings and perspectives on children's advertising in Macklin and Carlson (1999). Extensions of past research to new issues such as privacy regulations for children's personally identifiable information on the Internet are likely.

\section{Environmental Marketing Claims}

A major initiative by the FTC in 1992 was the issuance of the environmental marketing guides. Extensive hearings took place in December 1995 with respect to the revision of the guides. As part of the request for comments for the hearings (FTC 1995a), the Commission released several studies conducted by consumer researchers on perceptions of ozone and environmentally friendly claims (cf. Maronick and Andrews 1999) and interpretations of recyclable claims. Several consumer researchers participated in the hearings by discussing tracking studies on environmental claim use across product categories and geographical areas (Mayer et al. 1995). In addition, an entire issue of the Journal of Advertising (Summer 1995) was devoted to research on environmental marketing claims (see also Morris, Hastak, and Mazis 1995). One of the studies provided a thorough analysis of federal, state, and local agency policies with respect to environmental marketing claim regulation (Scammon and Mayer 1995). Recent discussion of fuel cell vehicles, life-cycle analysis, environmental seal systems, and 
new environmental marketing activities no doubt will provide researchers with opportunities for further study.

\section{Nutrition Labeling and Health Claims}

The implementation of the Nutrition Labeling and Education Act (1990) by the FDA's (1993) food labeling regulations and the FTC's (1994) operating policy statement on food advertising created many opportunities for researchers to examine unanswered questions. For example, a major section of the Spring 1996 issue of $J P P \& M$ was devoted to addressing nutrition issues such as the effectiveness of alternative labeling formats (Levy, Fein, and Schucker 1996), consumer processing of nutrient and health claims on packages (Ford et al. 1996), acquisition and comprehension of nutrition information (Moorman 1996), demographic profiles and food shopping preferences (Mathios 1996), and alternative reference points for the provision of daily reference value information (Barone et al. 1996). Additional studies varied nutrition labeling format information (Burton, Biswas, and Netemeyer 1994; Viswanathan 1994), studied age effects (Burton and Andrews 1996), conducted experimental and field studies of nutrient and health claim information (Andrews, Netemeyer, and Burton 1998; FTC 1998b; Ippolito and Mathios 1991; Roe, Levy, and Derby 1999), and examined interactions between claims and labeling (Keller et al. 1997; Mitra et al. 1999; Szykman, Bloom, and Levy 1997). In sum, it is apparent from prior research that nutrition information modality (e.g., labeling vs. claims), labeling and disclosure format (e.g,, adjectival, percentage value, absolute value), message content (e.g., reference value strength, nutrients included), and consumer characteristics (e.g., motivation, nutrition and health knowledge, age, opportunity) all play important roles in the effectiveness of nutrition labeling and claims. New venues for the application of these factors and associated theory are likely in the areas of dietary supplements and functional foods.

\section{Warnings and Disclosures}

A rich history of contributions exists on warnings and disclosures from our field and predates many of the nutrition studies just discussed. For example, special conferences on issues relating to warnings and disclosures (e.g., labeling and health risks [Mazis 1980]) were held several years ago, with numerous contributors and disciplines involved. However, similar to the recent special $J P P \& M$ section on nutrition, a special issue of $J P P \& M$ recently was devoted to the topic of warnings and disclosures (for contributors, see Spring 1998 issue of $J P P \& M$ ). This issue examined retail price disclosures, odds disclosures, superimposed video information, trademark disclaimers, alcohol warnings, OTC drug labeling, and the legal duty to warn. In general, a starting point for researchers in this area is to read Stewart and Martin's (1994) thorough examination of the intended and unintended consequences of warnings (see also the update by Stewart, Folkes, and Martin in this volume [Chapter 15]). In addition, Andrews and Netemeyer (1996) provided a review of the numerous alcohol warning research studies and examined related addiction issues and policy alternatives. For those interested in enhancing the effectiveness of product warning 
labels, the Bettman, Payne, and Staelin (1986) article offers many suggestions based on theories of information processing. No doubt, perceptual differences play an important role in the assessment and handling of risk from warnings, as indicated in Slovic, Fischhoff, and Lichtenstein (1980). Finally, Cox and colleagues (1997) offered a meta-analysis of the influence of warnings on behavior revealing the many difficulties of this relationship.

Disclosure research can be split into (1) the study of regulatory issues and (2) experimental work, especially in the area of advertising. For a thorough examination of the role of affirmative disclosures at the FTC, researchers are encouraged to read the series of studies offered by Wilkie in JPP\&M (e.g., in 1985). Other influential research includes Hoy and Stankey's (1993) extensive content analysis of advertising disclosures in the study of applications of the FTC's "clear and conspicuous standard." At present, the clear and conspicuous standard is being examined in light of the application of Commission rules and guides in new electronic media formats (FTC 1998c). Experimental work on advertising print disclosures can be found in Foxman, Muehling, and Moore (1988) and shows that disclosures can play an important role in highlighting the importance of associated ad copy. Finally, if clearly and prominently displayed, experimental manipulation of various ad disclosure statements has revealed that "evaluative" disclosures can have a stronger effect on nutrition beliefs than "absolute" or "relative" disclosure statements (Andrews, Netemeyer, and Burton 1998; see also FTC 1998b). In sum, and as found with studies of nutrition labeling and claims, research on warning and disclosure effectiveness ultimately depends on the strength of the message content, modality, format, source, and consumer factors.

\section{Theoretical Contributions to Consumer Protection Policy}

Numerous theoretical contributions to consumer protection policy have been made from the fields of psychology, marketing and consumer behavior, economics, and law. This section highlights examples of some of these contributions as extended and applied by scholars working in the marketing and consumer behavior disciplines.

Perhaps one of the most enduring contributions over the years has been the stages of information processing, as introduced by McGuire (1976, 1980). These eight stages (exposure, attention, comprehension, agreement, retention, retrieval, decision making, and action), coupled with communication factors (source, receiver, message, and modality), have been quite helpful in assessing the impact of deceptive and unfair ad campaigns, copy tests of such campaigns, and new public policy initiatives (e.g., trade rules, warning labels). Aspects of information processing apply to the study of information overload (Scammon 1977); comprehension, perception; and memory (Bettman 1979); miscomprehension (Jacoby and Hoyer 1982); learning processes (Mitchell 1983); and imagery (Lutz and Lutz 1977; Paivio 1969; Rossiter 1982). For example, studies of imagery and the dual coding of visual and verbal information have played an important role in the FDA's (1996) proposed tobacco regulations and the FTC's 
clear and conspicuous standard. Also, information-processing principles have been extended to children's advertising (Roedder 1981), package labeling (Bettman, Payne, and Staelin 1986), and warnings (Andrews and Netemeyer 1996; Hilton 1993; Stewart and Martin 1994).

A second area of impact has been the application of several theories of persuasion. Specifically, the hierarchy of effects model (Lavidge and Steiner 1961) outlines the process of awareness, knowledge, liking, preference, conviction, and purchase as well as later variations of cognitive, affective, and conative components (Barry 1987). This model is useful in measuring effects in deceptive and unfair ad cases (e.g., Cohen 1998). Other studies have extended knowledge of attribution, conformity, and susceptibility theories in the study of persuasive factors important in substance abuse intervention programs (Rose, Bearden, and Manning 1996). Comprehensive theoretical models in persuasion, such as the elaboration likelihood model (ELM) (Petty and Cacioppo 1986) and its extensions (Batra and Ray 1986; MacInnis and Jaworski 1989; Meyers-Levy and Malaviya 1999) and the theory of reasoned action (Ajzen and Fishbein 1980; Fishbein and Ajzen 1975), have integrated a multitude of persuasive theories and helped to explain consumer motivation, opportunity, ability, and experiences in processing marketing communications. Such information has been helpful in evaluating the success of consumer protection campaigns and regulations (e.g., nutrition information, energy labels, tobacco marketing restrictions). Theoretical frameworks of coping behavior and fear persuasion, such as the protection motivation model (Rogers 1975; Tanner, Hunt, and Eppright 1991), the parallel response model (Leventhal 1970), and risk perception research (Slovic, Fischhoff, and Lichtenstein 1980), have aided our understanding of the processing of warning labels and prevention programs. Likewise, prospect theory (Tversky and Kahneman 1981) can assist our knowledge of the weighing of negative and positive information in disclosures. Finally, psychological reactance theory (Brehm 1966) offers much insight into situations where consumers' personal freedom is believed to be restricted due to regulations (cf. Mazis 1975).

A third contributing area is theoretical research on ad claim processing. Specifically, ad claims in question may interact with other consumer "evidence" such as prior experience, involvement levels, and package labeling. The integrated information response model (Smith and Swinyard 1982) helps to explain consumer processing in such an interactive environment. Similarly, research by Deighton (1984) and Hoch and $\mathrm{Ha}$ (1986) examined the integration between advertising and trial experience, especially under varying levels of evidence ambiguity. Darley and Smith's (1993) "claim objectivity classification" has helped researchers in experimental studies on deceptive advertising. Similarly, economics of information theory (Ford, Smith, and Swasy 1990; Nelson 1974; Smith 1990) provides an important classification of ad claims according to search, experience, and credence attributes. For example, researchers comparing Lanham Act and FTC cases have applied this classification (Petty 1992), and economics of information theory has been used extensively in its application to FTC nutrition and environmental cases. Finally, contributions from the ad inferencing literature have provided critical linguistic and legal analyses of 
deceptive advertising content (Harris, Dubitsky, and Bruno 1983; Richards 1990; Shimp 1978, 1983).

A fourth area of theoretical contributions to consumer protection policy is the study of source effects. For example, Alba and Hutchinson's (1987) hypothesized effects on consumer expertise and knowledge and Kelman's (1961) model of source attributes (credibility, attractiveness, and power) and receiver processing modes (internalization, identification, and compliance) are helpful resources for the study of endorsements and testimonial advertising (FTC 1980; see also Kertz and Ohanian 1992).

\section{Cautions and Suggestions for Marketing and Public Policy Researchers}

To enhance contributions to consumer protection policy, several cautions and suggestions for marketing and consumer researchers are offered in this section. One general recommendation is that marketing and consumer researchers might try to become greater advocates of the many theoretical contributions studied in our field and applied in consumer protection policy. As shown in Figure 1.1, such marketing knowledge is likely to compete with long-standing theories from economics and law for the attention of consumer protection agency personnel. Thus, it is up to marketing scholars to demonstrate the value of theory from the marketing discipline in policy formation. The following specific suggestions apply both for those conducting academic research on public policy issues and for those involved in contract research (e.g., copy tests, rule evaluation) for consumer protection agencies.

\section{Issue Immersion}

The first suggestion to enhance contributions for consumer protection policy is that, before any research is conducted, it might be helpful to take the time to fully understand the nuances of the issue and why past research is deemed to be useful or irrelevant. Thus, it is very important to become immersed with the substantive public policy issue at hand and its many complexities. One method to accomplish this is to thoroughly examine the multiple sides and viewpoints on the issue (e.g., by speaking to staff attorneys, economists, and industry representatives). Information gained from agency sites on the Internet, conferences, hearings, special issues, retrospective sections (e.g., Spring $1997 J P P \& M$ ), and calls for research can be an invaluable planning tool. However, researchers might be cautious when secondary data sets become available in that the data might dictate the study objectives rather than the theory or public policy issue being examined. In such a scenario, a forcing of theory or public policy questions into the existing data set might be very transparent to consumer protection personnel and eventual reviewers. 


\section{Differing Perspectives}

When researchers enter the consumer protection arena, there exist two players-attorneys and economists - that already have established rules of procedure and conduct. The greatest chance of having an impact is to test public policy issues with an appreciation of their language and frameworks (e.g., legal process, legal cites, economic principles and analysis). Thus, enhancing one's familiarity with the economic and legal theories involved in a given public policy issue or case is a good idea. At the same time, with such an understanding of differing perspectives (cf. Mazis 1980), marketing and consumer researchers should be comfortable in effectively communicating the contributions from our field to other disciplines.

\section{Theoretical Grounding}

Another suggestion is that researchers might consider carefully the role of theory in the formation of studies on consumer protection topics. The consideration of theory firmly grounds our application tests about public policy in offering a systematic structure (e.g., nomological network of relationships) capable of explaining and predicting future issues and events (cf. Hunt 1991, p. 4). Without theory, our tests might be applicable only in isolation and will not offer the richer program of research afforded by links to a network of predicted relationships useful in research extensions. This reliance also bolsters the discussion of contract studies under cross-examination by integrating the study findings within the larger network of research associated with the theory (or theories). Moreover, many avenues exist for the role of theory in marketing and public policy research. For example, theoretical frameworks may be subjected to specific application tests in the context of a marketing and public policy issue. Alternatively, a series of public policy application tests may help to form or alter present theories through the process of induction. Or, one might wish to pit theory against theory in an application test in the spirit of "strong inference" (Platt 1964). For example, a multitude of theories exist helping to explain and predict effects in conducting warnings, disclosures, and ad claim studies (e.g., activation theory, adaptation-level theory, economics of information, the ELM, integrated information response theory, legal theories, parallel response theory, prospect theory, protection motivation model, theory of reasoned action [or behavior]).

\section{Striking a Balance}

One caution in theory development work, however, is that it is possible to oversimplify the public policy issue in question (Wilkie 1997). As indicated by Petty and Cacioppo (1996), researchers might attempt to develop not only the theoretical aspects of their work but also try to link these with having a substantive impact on society. Moreover, the very nature of a theory is that it is empirically testable (Hunt 1991), and in our field this means a closer representation 
and linkage with the specific public policy issues in question (Shimp 1994). In so doing, bowever, researchers face a difficult balancing act in trying to address concerns of both internal validity (e.g., with causal inferences) and external validity (e.g., generalizability of the findings to other settings) in studies (Cook and Campbell 1979). As suggested previously, issue immersion, the use of a realistic methodology, and consideration of the appropriate theoretical domain are likely to help in achieving such a balance.

\section{Research Design and Rigor}

Some have suggested that if the data are likely to be used by consumer protection agencies involved in litigation (e.g., a FTC trial), then a researcher should think of the most thorough journal review that he or she has ever received. Under the discovery process, one's data, questionnaires, and pretest results will be made available to the other side, which will hire an expert to find flaws in one's research. If the case proceeds to trial, then the researcher might be subjected to a cross-examination of the materials and prior deposition comments. In general, and in the context of providing extrinsic evidence for enforcement actions, the researcher's adherence to "generally accepted principles" and maintaining of independence (as opposed to advocacy) are important practices in ensuring a successful outcome (Maronick 1991). Also, in the design of studies for consumer protection agencies, the objectives for the study might be at odds with the researcher's own objectives, training, and methods in performing such studies. If the goal is eventual journal publication of the study (assuming that it is made public), then this might alter the beginning strategy for the design. For example, there might be pressure to test a multitude of warning and disclosure cells based on pending case scenarios rather than to use a systematic variation of content, control groups, and ties to theory. On the other hand, the use of realistic stimuli, procedures, and a representative sample of the policy issue being studied helps to enhance the usefulness of the results for consumer protection policy and to increase its chances for journal publication.

\section{Multiple Approaches and Programmatic Research}

With respect to methodology, the consideration of multiple approaches (e.g., surveys, qualitative studies, experimentation in the field and laboratories, metaanalyses, legal and policy analyses, and case studies) is encouraged in addressing a given public policy issue. For example, the combination of ethnographic fieldwork and a follow-up study using experimental variables discovered from the first study might provide additional insight into the issue. Also, as advocated elsewhere (cf. Andreasen 1997; Bloom 1997), the study of actual behavior with respect to the policy issue can enhance the contribution of the research. Such multiple approaches add value to the contributions from the marketing discipline to both policy formation and policy enforcement.

Another observation is that some of the more influential articles contributing to consumer protection policy and thought are the products of long-term pro- 
grammatic research in an area. This is evident in the review of contributors mentioned in this chapter on multiple occasions in a given policy area. Finally, researchers are encouraged to "stay the course" over the years in addressing public policy research, even though funding might fluctuate according to the political interest levels in public policy activity. The reason is that if a proposed study is well done, then support usually will follow.

Future Research Directions

There are several needs for research on consumer protection issues that are likely to continue for some time and are addressed in this final section. However, one way in which to keep abreast of consumer protection issues is to be a frequent visitor to congressional, federal agency, consumer group, and trade association Web sites that are likely to share current topics of importance.

The issue of privacy of personal information offered, required, or captured in e-commerce, computer sensors and microchip technology, children's Web sites, Internet banking, electronic transfer of medical records, on-line profiling (FTC $1999 \mathrm{c}$ ), and information transfer between countries with varying privacy policies is likely to be debated for some time (see Spring 2000 issue of $J P P \& M$ ). For example, the FTC's (1999b) recent children's advertising privacy protection rule is a result of congressional action in this area. Parental verification is needed before companies can collect personally identifiable information on the Internet from children under 13 years of age. However, there exists little consumer research as to how children might respond to disclosures and requests for parental approval on Web sites. A rich body of theory on children's processing of information exists (cf. Macklin and Carlson 1999) and might be applied in this setting or in other policy issues with children (e.g., reactions to disclosures of violence found in video games). Also, the study of "opt-in" versus "opt-out" strategies for protecting the privacy of information might be examined, especially if there are differences in other parts of the world (e.g., EU).

A related topic that has received some attention recently is the applicability of FTC rules and guides in electronic media (FTC 1999a). However, little is known about how consumers process Web sites, ad banners, and corporate public relations pages over the Internet. Exactly where should disclosures be placed in Web-based advertising? Is it important that consumers understand the corporate sources of the sites? How will deception and unfairness policies apply in this new environment? An understanding of underlying economic principles (e.g., economics of information) also might be important in the FTC's application of e-commerce issues. For example, economics of information principles would argue that more resources should be applied to cases of fraud over the Internet than to shopper-or search-related Internet issues. Whereas such a tradeoff certainly is open to debate, marketers might consider the underlying principles that could be applied in such a policy analysis.

Corrective advertising represents a potentially important remedy tool at the FTC. Recently, the final order in the Novartis (1999) case required ads and pack- 
aging for Doan's Pills to include, in a clear and conspicuous manner, the following message: "Although Doan's is an effective pain reliever, there is no evidence that Doan's is more effective than other pain relievers for back pain." The corrective statement was to be carried on all packaging and ads for one year (except radio and television ads of 15 seconds or less) and until Novartis expended a total of $\$ 8$ million on Doan's advertising. In general, research questions remain regarding the necessary length of time and impact of lingering beliefs needed for corrective ad remedies. Also, opportunities exist to examine systematically the effectiveness of different corrective ad language, measures, formats, and media placements.

In addition to the need for study of consumer perceptions of dietary supplement claims (FTC 1998a), little is known regarding how consumers will respond to claims, evidence, and disclosures for functional foods appearing in the marketplace. Such promotion might be viewed in the same category as a material credence claim due to its focus on health issues; therefore, it might receive greater scrutiny. Functional foods have added herbs, additives, cultures, and vitamins with medicinal claims of aiding depression, lessening symptoms of colds, improving one's ability to concentrate, and so on (Brophy and Schardt 1999). However, little research exists as to how consumers will react to such claims, evidence, and disclosures. Do consumers have the necessary knowledge to interpret the safety and efficacy of evidence advertised about such foods? Do they understand the difference between "structure function claims" (e.g., "promotes a healthy heart"- yet with high levels of fat) versus health claims (e.g., "may reduce the risk of heart disease"-meeting disqualifying levels for negative nutrients such as total fat)?

Other topics for possible research include debates regarding the trade-offs between domestic consumer protection laws and international trade agreements (e.g., North American Free Trade Agreement, World Trade Organization [WTO]). Similarly, marked differences exist between the United States and other countries on the determination and regulation of deceptive, unfair, and comparative advertising (Petty 1997). As partnerships, agreements, and markets evolve (e.g., EU, WTO), is a harmonization and consistency of ad regulations best for consumers and competition? Finally, much can be done in the study of the effectiveness of different anti-tobacco (as well as anti-alcohol abuse and anti-gambling) ads that differ in their types of appeals used across jurisdictions (cf. Pechmann and Goldberg 1998). Thus, many opportunities exist for public policy scholars on consumer protection matters. It is in our best interest as a field, which is valued by consumer protection officials, to play a proactive role in contributing knowledge in this area.

\section{References}

Ajzen, Icek and Martin Fishbein (1980), Understanding Attitudes and Predicting Social Behavior. Englewood Cliffs, NJ: Prentice Hall.

Alba, Joseph W. and J. Wesley Hutchinson (1987), "Dimensions of Consumer Expertise," Journal of Consumer Research, 13 (March), 411-54. 
Andreasen, Alan R. (1997), "From Ghetto Marketing to Social Marketing: Bringing Social Relevance to Mainstream Marketing," Journal of Public Policy \& Marketing. 16 (Spring), 129-31.

Andrews, J. Craig (1996), "Overview: The Role of Consumer Research in National Advertising Regulation," Advertising Law Anthology, 19 (Part 1, January-June), xixxxvii,

and Thomas J. Maronick (1995), “Advertising Research Issues from FTC versus Stouffer Foods Corporation," Journal of Public Policy \& Marketing, 14 (Fall), 301-9.

and Richard G. Netemeyer (1996), "Alcohol Warning Label Effects: Socialization, Addiction, and Public Policy Issues," in Marketing and Consumer Research in the Public Interest, Ronald Paul Hill, ed. Thousand Oaks, CA: Sage, 153-75.

- a a Claims in Advertising," Journal of Marketing, 62 (October), 62-75.

Andrews, Rick and George R. Franke (1991), "The Determinants of Cigarette Consumption: A Meta-Analysis," Journal of Public Policy \& Marketing, 10 (Spring), 81-100.

Barlow, Todd and Michael S. Wogalter (1993), "Alcoholic Beverage Warnings in Magazine and Television Advertisements," Journal of Consumer Research, 20, 147-56.

Barone, Michael J., Randall L. Rose, Kenneth C. Manning, and Paul W. Miniard (1996), "Another Look at the Impact of Reference Information on Consumer Impressions of Nutrition Information," Journal of Public Policy \& Marketing, 15 (Spring), 55-62.

Barry, Thomas E. (1987), "The Development of the Hierarchy of Effects," in Current Issues and Research in Advertising, James H. Leigh and Claude R. Martin, Jr., eds. Ann Arbor: University of Michigan Press, 251-96.

Batra, Rajeev and Michael L. Ray (1986), "Situational Effects of Advertising Repetition: The Moderating Influence of Motivation, Ability, and Opportunity to Respond," Journal of Consumer Research, 12 (March), 432-45.

Bernhardt, Kenneth L. and Ronald Stiff (1981), "Public Policy Update: Perspective in the Federal Trade Commission," in Advances in Consumer Research, Vol. 8, Kent B. Monroe, ed. Ann Arbor, MI: Association for Consumer Research, 452-54.

Bernstein, Joan Z. (1996), "Federal Trade Commission Solicits Consumer Research," in Advances in Consumer Research, Vol. 23, Kim P. Corfman and John G. Lynch, Jr., eds. Provo, UT: Association for Consumer Research, 313-15.

Bettman, James R. (1979), An Information Processing Theory of Consumer Choice. Reading, MA: Addison-Wesley.

- John W. Payne, and Richard Staelin (1986), "Cognitive Considerations in Designing Effective Labels for Presenting Risk Information," Journal of Public Policy \& Marketing, 5, 1-28.

Bhalla, Gaurav and John L. Lastovicka (1984), "The Impact of Changing Cigarette Warning Message Content and Format," in Advances in Consumer Research, Vol. II. Thomas C. Kinnear, ed. Provo, UT: Association for Consumer Research, 305-10.

Bloom, Paul N. (1997), "Field of Marketing and Public Policy: Introduction and Overview," Journal of Public Policy \& Marketing, 16 (Spring), 126-28.

- and Gregory T. Gundlach, eds. (2000), Handbook of Marketing and Society. Thousand Oaks, CA: Sage.

Boddewyn, J. J. (1994), "Cigarette Advertising Bans and Smoking: The Flawed Policy Connections," International Journal of Advertising, 13 (4). 311 - 32.

Brehm, Jack W. (1966), A Theory of Psychological Reactance. New York: Academic Press.

Brophy, Beth and David Schardt (1999), "Functional Foods," Nutrition Action Healthletter, April, 3-7. 
Brucks, Merrie, Gary M. Armstrong, and Marvin E. Goldberg (1988), "Children's Use of Cognitive Defenses against Television Advertising: A Cognitive Response Approach," Journal of Consumer Research, 14 (4), 471-82.

Burke, Raymond R., Wayne S. DeSarbo, Richard L. Oliver, and Thomas S. Robertson (1988), "Deception by Implication: An Experimental Investigation," Journal of Consumer Research, 14 (March), 483-94.

Burton, Scot and J. Craig Andrews (1996), "An Examination of Age, Product Nutrition, and Nutrition Label Effects on Consumer Perceptions and Product Evaluations." Journal of Consumer Affairs, 30 (Summer), 68-89.

_ Abe Biswas, and Richard G, Netemeyer (1994), "Effects of Alternative Nutrition Label Formats and Nutrition Reference Information on Consumer Perceptions, Comprehension, and Product Evaluations," Journal of Public Policy \& Marketing, 13 (Spring), 36-47.

Calfee, John E. (1986), "The Ghost of Cigarette Advertising Past," Regulation, NovemberDecember, 35-45.

"Campbell Soup Company and the Federal Trade Commission" (1992), in Ethics in Marketing, N. Craig Smith and John A. Quelch, eds. Homewood, IL: Irwin, 636-40.

Center for Science in the Public Interest (1994), Food Advertising Chaos: The Case for Reform. Washington, DC: CSPI.

Cliffdale Associates Inc, (1984), 103 FTC 110-202.

Cohen, Dorothy (1980), “The FTC's Advertising Substantiation Program," Journal of Marketing, 44 (Winter), 26-35.

- (1982), "Unfairness in Advertising Revisited," Journal of Marketing, 46 (Winter), 73-80.

(1995), Legal Issues in Marketing Decision Making. Cincinnati, OH: SouthWestern.

Cohen, Joel B. (1990), "Charting a Public Policy Agenda for Cigarettes," in Marketing and Advertising Regulation: The Federal Trade Commission in the 1990s, Patrick E. Murphy and William L. Wilkie, eds. Notre Dame, IN: University of Notre Dame Press, 234-54.

- (1998), Expert Testimony in the Matter of R. J. Reynolds Tobacco Company, FTC Docket No. 9285, November 16, 1-66.

Cook, Thomas D. and Donald T. Campbell (1979), Quasi-Experimentation: Design and Analysis Issues for Field Settings. Boston: Houghton Mifflin.

Cox, Eli P., III, Michael S. Wogalter, Sara L. Stokes, and Elizabeth J. Tipton Murff (1997), "Do Product Warnings Increase Safe Behavior? A Meta-Analysis," Journal of Public Policy \& Marketing, 16 (Fall), 195-204.

Darley, William K. and Robert E. Smith (1993). "Advertising Claim Objectivity: Antecedents and Effects," Journal of Marketing, 57 (October), 100-13.

Deighton, John (1984), "The Interaction of Advertising and Evidence," Journal of Consumer Research, 11 (December), 763-70.

Eggland's Best Inc. (1994), FTC Docket No, C-3520 (consent agreement), August 15.

Federal Trade Commission (1978), FTC Staff Report on Television Advertising to Children. Washington, DC: FTC.

(1979), Policy on Consumer Information Remedies. Washington, DC: FTC.

- (1980), Guides Concerning Use of Endorsement and Testimonials in Advertising, 16 CFR 255.

(1981), "Children's Advertising: Termination of Federal Trade Commission Rulemaking Proceeding," Federal Register, October 2, 48710-14.

(1992), Guides for the Use of Environmental Claims. Washington, DC: FTC. (Revised 1996, 1998) 
(1993), Trade Rule Pursuant to the Telephone Disclosure and Dispute Resolution Act (900 number rule), 16 CFR 308, August 9, 42364-406.

(1994), Enforcement Policy Statement on Food Advertising. Washington, DC: FTC.

(1995a), FTC Survey" (n, 6), in "Request for Comment Concerning Environmental Marketing Guides, 16 CFR, Part 260, 1-4.

(1995b), Telemarketing Sales Rule, 16 CFR 310.

(1998a), Dietary Supplements: An Advertising Guide for Industry. Washington,

DC: FTC,

(1998b), Generic Copy Test of Food Health Claims in Advertising. Washington,

DC: FTC.

(1998c), Interpretation of Rules and Guides for Electronic Media: Request for Comment, 16 CFR, Chapter 1. May 6, 24996-5005.

(1998d), Privacy Online Report to Congress. Washington, DC: FTC.

(1999a), Announcement of Date of Public Workshop on the Interpretation of Rutes and Guides for Electronic Media, Procedure for Requesting to Participate, and Request for Submission of Advertisements. Washington, DC: FTC.

(1999b), Children's Online Privacy Protection Rule, 16 CFR 312, November 3.

(1999c). Notice on Department of Commerce and Federal Trade Commission Public Workshop on Online Profiling, Docket No. 990811219-9219-01, September 15.

Federal Trade Commission Act Amendments of 1994, Statutes at Large, 108, 1691. (Public Law 103-312).

Fishbein, Martin and Icek Ajzen (1975), Belief, Attitude, Intention, and Behavior: An Introduction to Theory and Research. Reading, MA: Addison-Wesley.

Food and Drug Administration (1993), Food Labeling; General Provisions . . . Final Rules, 21 CFR, Part I, January 6, 2302-964.

(1996), Regulations Restricting the Sale and Distribution of Cigarettes and Smokeless Tobacco to Protect Children and Adolescents: Final Rule, 21 CFR 801, Part 2, August 28, 44396-5318.

Food and Drug Administration v. Brown \& Williamson Tobacco Corporation (2000), 120 S.Cl, 1291-333.

Ford, Gary T. and John E. Calfee (1986), "Recent Developments in FTC Policy on Deception," Journal of Marketing, 50 (July), 82-103.

—, Manoj Hastak, Anusree Mitra, and Debra J. Ringold (1996), "Can Consumers Interpret Nutrition Information in the Presence of a Health Claim? A Laboratory Investigation," Journal of Public Policy \& Marketing, 15 (Spring), 16-27.

—, Darlene B. Smith, and John L. Swasy (1990), "Consumer Skepticism of Advertising Claims: Testing Hypotheses from Economics of Information," Journal of Consumer Research, 16 (March), 433-41.

Foxman, Ellen, Darrel D. Muehling, and Patrick A. Moore (1988), "Disclaimer Footnotes in Ads: Discrepancies between Purpose and Performance," Journal of Public Policy \& Marketing, 7, 127-37.

Goldberg, Marvin E., Gerald J. Gorn, and Wendy Gibson (1978), “TV Messages for Snack and Breakfast Foods: Do They Influence Children's Preferences?" Journal of Consumer Research, 5 (September), 73-81.

and Lynn T. Kozlowski (1997), "Loopholes and Lapses in the '1997 Tobacco Agreement': Some Devils in the Marketing Details," Journal of Public Policy \& Marketing, 16 (Fall), 345-51.

Gregan-Paxton, Jennifer and Deborah Roedder John (1997), "The Emergence of Adaptive Decision Making in Children," Journal of Consumer Research, 24 (June), 43-56. 
Greyser, Stephen A. (1997), "Consumer Research and the Public Policy Process: Then and Now," Journal of Public Policy \& Marketing, 16 (Spring), 137-38.

Harris, Richard Jackson, Tony M. Dubitsky, and Kristin Jo Bruno (1983), "Psycholinguistic Studies of Misleading Advertising," in Information Processing Research in Advertising, Richard J. Harris, ed. Hillsdale, NJ: Lawrence Erlbaum, 24I-62.

Hasbro Inc. (1993), FTC File No. 912-3369 (consent agreement), April 15.

(1996), FTC Docket No. C-3447, Civil Action No. 96-451P (order violation and civil penalty), August 7.

Hill, Ronald Paul, ed. (1996), Marketing and Consumer Research in the Public Interest. Thousand Oaks, CA: Sage.

Hilton, Michael E. (1993), "An Overview of Recent Findings on Alcoholic Beverage Warning Labels," Journal of Public Policy \& Marketing, 12 (Spring), 1-9.

Hoch, Stephen J. and Young-Won Ha (1986), "Consumer Learning: Advertising and the Ambiguity of Product Experience," Journal of Consumer Research, 13 (September), 221-32.

Hollander, Stanley C., William W. Keep, and Roger Dickinson (1999), "Marketing Public Policy and the Evolving Role of Marketing Academics: An Historical Perspective," Journal of Public Policy \& Marketing, 18 (Fall), 265-69.

Hoy, Maria Grubbs and Michael J. Stankey (1993), "Structural Characteristics of Televised Advertising Disclosures: A Comparison with the FTC Clear and Conspicuous Standard," Journal of Advertising, 22 (June), 47-59.

Hunt, Shelby D. (1978), "A General Paradigm of Marketing: In Support of the Three Dichotomies Model," Journal of Marketing, 40 (July), 107-10.

- (1991), Modern Marketing Theory: Critical Issues in the Philosophy of Marketing Science. Cincinnati, $\mathrm{OH}$ : South-Western.

Ippolito, Pauline M. and Alan D. Mathios (1991), "Health Claims in Food Marketing: Evidence on Knowledge and Behavior in the Cereal Market," Journal of Public Policy \& Marketing, 10 (1), 15-32.

Jacoby, Jacob and Wayne D. Hoyer (1982), "Viewer Miscomprehension of Televised Communication: Selected Findings," Journal of Marketing, 46 (Fall), 12-26.

- and George J. Szybillo (1995), "Consumer Research in FTC v. Kraft: A Case of Heads We Win, Tails You Lose?" Journal of Public Policy \& Marketing, 14 (Spring), $1-14$.

Johar, Gita Venkataramani (1995), "Consumer Involvement and Deception from Implied Advertising Claims," Journal of Marketing Research, 32 (August), 267-79.

Jones, Mary Gardiner (1990), "Marketing Academics at the FTC: Reflections and Recommendations," in Marketing and Advertising Regulation: The Federal Trade Commission in the 1990s, Patrick E. Murphy and William L. Wilkie, eds. Notre Dame, IN: University of Notre Dame Press, 216-20.

- and Murray Silverman (1973), "Is There a Role for Research in the Federal Trade Commission?" in Proceedings of Workshop on Public Policy and Marketing Practices, Fred C. Allvine, ed. Chicago: American Marketing Association, 69-81.

Keller, Punam Anand and Lauren Goldberg Block (1996), "Increasing the Persuasiveness of Fear Appeals: The Effect of Arousal and Elaboration," Journal of Consumer Research, 22 (March), 448-59.

Keller, Scott B., Mike Landry, Jeanne Olson, Anne M. Velliquette, Scot Burton, and J. Craig Andrews (1997), "The Effects of Nutrition Package Claims, Nutrition Facts Panels, and Motivation to Process Nutrition Information on Consumer Product Evaluations," Journal of Public Policy \& Marketing, 16 (Fall), 256-69.

Kelman, Herbert C. (1961), "Processes of Opinion Change," Public Opinion Quarterly, 25 (Spring), 57-58. 
Kertz, Consuelo Lauda and Roobina Ohanian (1992), "Source Credibility, Legal Liability, and the Law of Endorsements," Journal of Public Policy \& Marketing, 11 (Spring), 12-23.

Kinnear, Thomas C. (1997), "An Historic Perspective on the Quantity and Quality of Marketing and Public Policy Research," Journal of Marketing \& Public Policy, 16 (Spring), 144-46.

Kraft Inc. (1991), Commision Decision, 114 FTC 40-46, 116-51; aff'd, Kraft Inc. v. FTC (1992), 970 F.2d 311 (7th Cir.), 311-28; cert. denied (1993), 113 S.Ct., 1254.

Laczniak, Russell N. and Sanford Grossbart (1990), "An Assessment of Assumptions Underlying the Reasonable Consumer Element in Deceptive Advertising Policy," Journal of Public Policy \& Marketing, 9, 85-99.

Lavidge, Robert J. and Gary A. Steiner (1961), "A Model for Predictive Measurements of Advertising Effectiveness," Journal of Marketing, 25 (October), 59-62.

Leventhal, Howard (1970), "Findings and Theory in the Study of Fear Communications," in Advances in Experimental Social Psychology, Vol. 5, Leonard Berkowitz, ed. New York: Academic Press, 119-86.

Levy, Alan S., Sara B. Fein, and Raymond E. Schucker (1996), "Performance Characteristics of Seven Nutrition Label Formats," Journal of Public Policy \& Marketing, 15 (1), 1-15.

Lutz, Kathy A. and Richard J, Lutz (1977), "The Effects of Interactive Imagery on Learning: Application to Advertising," Journal of Applied Psychology, 62 (August), 493-98.

MacInnis, Deborah J. and Bernard J. Jaworski (1989), "Information Processing from Advertisements: Toward an Integrative Framework," Journal of Marketing, 53 (October), 1-23.

Macklin, M. Carole (1985), "Do Young Children Understand the Selling Intent of Commercials?" Journal of Consumer Affairs, 19 (2), 293-304.

- and Les Carlson, eds. (1999), Advertising to Children: Concepts and Controversies. Thousand Oaks, CA: Sage.

Maronick, Thomas J. (1990), "Current Role of Research at the Federal Trade Commission," in Marketing and Advertising Regulation: The Federal Trade Commission in the 1990s, Patrick E. Murphy and William L. Wilkie, eds. Notre Dame, IN: University of Notre Dame Press, 345-55.

(1991), "Copy Tests in FTC Deception Cases: Guidelines for Researchers," Journal of Advertising Research, 31 (December), 9-17.

and J. Craig Andrews (1999), "The Role of Qualifying Language on Consumer Perceptions of Environmental Claims," Journal of Consumer Affairs, 33 (Winter), 297-320.

Martin, Mary C. (1997), "Children's Understanding of the Intent of Advertising: A MetaAnalysis," Journal of Public Policy \& Marketing, 16 (Fall), 205-16.

Mathios, Alan D. (1996), "Socioeconomic Factors, Nutrition, and Food Choices: An Analysis of the Food Dressing Market," Journal of Public Policy \& Marketing, 15 (Spring), 45-54.

Mayer, Robert N., Jason Gray-Lee, Debra L. Scammon, and Brenda J. Cude (1995), Trends in Environmental Marketing Claims since the FTC Guides. Salt Lake City: University of Utah, Department of Family and Consumer Studies.

Mazis, Michael B. (1975), “Antipollution Measures and Psychological Reactance Theory: A Field Experiment," Journal of Personality and Social Psychology, 31, 654-60.

(1980), "An Overview of Product Labeling and Health Risks," in Banbury Report 6: Product Labeling and Health Risks, Louis A. Morris, Michael B. Mazis, and Ivan Barofsky, eds. Cold Spring Harbor, NY: Cold Spring Harbor Laboratory, 3-11. 
(1997), "Marketing and Public Policy: Prospects for the Future," Journal of Public Policy \& Marketing, 16 (Spring), 139-43.

McGuire, William J. (1962), "Persistence of the Resistance to Persuasion Induced by Various Types of Prior Belief Defenses," Journal of Abnormal and Social Psychology, 64, 241-48.

(1976), "Some Internal Psychological Factors Influencing Consumer Choice," Journal of Consumer Research, 4 (March), 302-19.

(1980), "The Communication-Persuasion Model and Health-Risk Labeling," in Banbury Report 6: Product Labeling and Health Risks, Louis A. Morris, Michael B. Mazis, and Ivan Barofsky, eds. Cold Spring Harbor, NY: Cold Spring Harbor Laboratory, 99-122.

Meyers-Levy, Joan and Prashant Malaviya (1999), "Consumers' Processing of Persuasive Advertisements: An Integrative Framework of Persuasion Theories," Journal of Marketing, 63 (Special Issue), 45-60.

Mitchell, Andrew A. (1983), "Cognitive Processes Initiated by Exposure to Advertising," in Information Processing Research in Advertising, Richard Jackson Harris, ed. Hillsdale, NJ: Lawrence Erlbaum, 13-42.

Mitra, Anusree, Manoj Hastak, Gary T. Ford, and Debra Jones Ringold (1999), "Can the Educationally Disadvantaged Interpret the FDA-Mandated Nutrition Facts Panel in the Presence of an Implied Health Claim?" Journal of Public Policy \& Marketing, 18 (Spring), 106-17.

Monroe, Kent B., William L. Wilkie, Linda J. McAleer, and Albert R. Wildt (1986), "Report of the AMA Task on the Development of Marketing Thought," in Marketing Education: Knowledge Development, Dissemination, and Utilization, Joseph Guiltinan and Dale Archabal, eds. Chicago: American Marketing Association, 8-9.

Moorman, Christine (1996), "A Quasi-Experiment to Assess the Consumer and Informational Determinants of Nutrition Information Processing Activities: The Case of the Nutrition Labeling and Education Act," Journal of Public Policy \& Marketing, 15 (Spring), 28-44.

Morgan, Fred W. (1990), "Judicial Standards for Survey Research: An Update and Guidelines," Journal of Marketing, 54 (January), 59-70.

Morris, Louis, Manoj Hastak, and Michael Mazis (1995), "Consumer Comprehension of Environmental Advertising and Labeling Claims," Journal of Consumer Affairs, 29 (2), 328-50.

Murphy, Patrick E. (1990), "Past FTC Participation by Marketing Academics," in Marketing and Advertising Regulation: The Federal Trade Commission in the 1990s, Patrick E. Murphy and William L. Wilkie, eds. Notre Dame, IN: University of Notre Dame Press, 205-15.

Murray, Noel M., Lalita A. Manrai, and Ajay K. Manrai (1993), "Public Policy Relating to Consumer Comprehension of Television Commercials: A Review and Some Empirical Results," Journal of Consumer Policy, 16 (2), 145-70.

Nelson, Phillip (1974), "Advertising as Information," Journal of Political Economy, 78 (March-April), 729-54.

Novartis Corporation (1999), Commission Decision, FTC Docket No. 9279, May 27, $1-38$.

Nutrition Labeling and Education Act (1990), Public Law 101-535, 21 U.S.C. 301, November 8.

Olson, Jerry C. and Philip A. Dover (1978), "Cognitive Effects of Deceptive Advertising," Journal of Marketing Research, 15 (February), 29-38.

Owen, Debra K, and Joyce E. Plyler (1991), "The Role of Empirical Evidence in the Federal Regulation of Advertising," Journal of Public Policy \& Marketing, 10(1), 1-14. 
Paivio, Allan (1969), "Mental Imagery in Associative Learning and Memory," Psychological Review, 76 (May), 241-63.

Pappalardo, Janis K. (1997), "The Role of Consumer Research in Evaluating Deception: An Economist's Perspective," Antitrust Law Journal, 65, 793-812.

Pechmann, Cornelia (1996), "Do Consumers Overgeneralize One-Sided Comparative Price Claims, and Are More Stringent Regulations Needed?" Journal of Marketing Research, 33 (May), 150-62.

and Marvin E. Goldberg (1998), "Should Anti-Smoking Ads Attempt to Denormalize Tobacco Use? Alternative Perspectives and Theoretical Frameworks," paper presented at the meeting of the Association for Consumer Research, October, Montreal.

- and S. Ratneshwar (1994), "The Effects of Antismoking and Cigarette Advertising on Adolescents' Perceptions of Peers Who Smoke," Journal of Consumer Research, 21 (September), 236-51.

Petty, Richard E. and John T. Cacioppo (1986), Communication and Persuasion: Central and Peripheral Routes to Attitude Change. New York: Springer-Verlag.

- and - (1996), "Addressing Disturbing and Disturbed Consumer Behavior: Is It Necessary to Change the Way We Conduct Behavior Science?" Journal of Marketing Research, 33 (February), 1-8.

Petty, Ross D. (1992), The Impact of Advertising Law on Business and Public Policy. Westport, CT: Quorum Books.

(1997). "Advertising Law in the United States and the European Union," Journal of Public Policy \& Marketing, 16 (Spring), 2-13.

(1999), "Tobacco Marketing Restrictions in the Multistate Attorneys General Settlement: Is This Good Public Policy?" Journal of Public Policy \& Marketing, 18 (Fall), 249-57.

Platt, John (1964), "Strong Inference," Science, October, 347-53.

Plevan, Kenneth A. and Miriam L. Siroky (1991), Advertising Compliance Handbook, 2nd ed. New York: Practicing Law Institute.

Pollay, Richard W., S. Siddarth, Michael Siegel, Anne Haddix, Robert Merritt, Gary A. Giovino, and Michael Ericksen (1996), "The Last Straw? Cigarette Advertising and Realized Market Shares among Youths and Adults, 1979-1993," Journal of Marketing, 60 (April), 1-16.

Preston, Ivan L. (1987), "Extrinsic Evidence in Federal Trade Commission Deceptiveness Cases," Columbia Business Law Review, 3, 633-94.

(1992), "The Scandalous Record of Avoidable Errors in Expert Evidence Offered in FTC and Lanham Act Deceptiveness Cases," in Proceedings of the 1992 Marketing and Public Policy Conference, Paul N. Bloom and Richard G. Starr, Jr., eds. Chapel Hill: University of North Carolina Press, 2-19.

(1995), "Unfairness Developments in FTC Advertising Cases," Journal of Public Policy \& Marketing, 14 (Fall), 318-20.

Richards, Jef I. (1990), Deceptive Advertising; Behavioral Study of a Legal Concept. Hillsdale, NJ: Lawrence Erlbaum.

Rindfleisch, Aric and David Crockett (1999), "Cigarette Smoking and Perceived Risk: A Multidimensional Investigation," Journal of Public Policy \& Marketing, 18 (Fall), 159-71.

Roe, Brian, Alan S. Levy, and Brenda M. Derby (1999), "The Impact of Health Claims on Consumer Search and Product Evaluation Outcomes: Results from FDA Experimental Data," Journal of Public Policy \& Marketing, 18 (Spring), 89-105. 
Roedder, Deborah L. (1981), “Age Differences in Children's Responses to Television Advertising: An Information-Processing Approach," Journal of Consumer Research. 8 (September), 144-53.

Rogers, Ronald W. (1975), "A Protection Motivation Theory of Fear Appeals and Attitude Change," Journal of Psychology, 91, 93-114.

Rose, Randall L., William O. Bearden, and Kenneth C. Manning (1996), “Using Individual Differences to Segment the 'Market' for an Attribution-Based Substance Abuse Intervention Program," Journal of Public Policy \& Marketing, 15 (Fall), 252-62.

Rossiter, John R. (1982), "Visual Imagery: Applications to Advertising," in Advances in Consumer Research, Vol. 9, Andrew A. Mitchell, ed, Ann Arbor, MI: Association for Consumer Research, 101-6.

Russo, J. Edward, Barbara L. Metcalf, and Debra Stephens (1981), "Identifying Misleading Advertising," Journal of Consumer Research, 8 (September), 119-31.

Scammon, Debra L. (1977), " 'Information Load' and Consumers," Journal of Consumer Research, 4 (December), 148-55.

and Robert N. Mayer (1995), "Agency Review of Environmental Claims: Caseby-Case Decomposition of the Issues," Journal of Advertising, 24 (Summer), 33-43.

Schultz, William B. (1996), "Food and Drug Administration's Suggested Consumer Research Ideas," in Advances in Consumer Research, Vol. 23, Kim P. Corfman and John G. Lynch, Jr., eds. Provo, UT: Association for Consumer Research, 316.

Shimp, Terence A. (1978), "Do Incomplete Comparisons Mislead?" Journal of Advertising Research, 18, 21-27.

(1983), "Evaluative Verbal Content and Deception in Advertising: A Review and Critical Analysis," in Information Processing Research in Advertising, Richard J. Harris, ed. Hillsdale, NJ: Lawrence Erlbaum, 195-216.

- (1994), "Academic Appalachia and the Discipline of Consumer Research," in Advances in Consumer Research, Vol. 21, Chris T. Allen and Deborah Roedder John, eds. Provo, UT: Association for Consumer Research, 1-7.

Simonson, Alexander (1995), " 'Unfair' Advertising and the FTC: Structural Evolution of the Law and Implications for Marketing and Public Policy," Journal of Marketing \& Public Policy, 14 (Fall), 321-27.

Slovic, Paul, Baruch Fischhoff, and Sarah Lichtenstein (1980), "Informing People about Risk." in Banbury Report 6: Product Labeling and Health Risks, Louis Morris, Michael Mazis, and Ivan Barofsky, eds. Cold Spring Harbor, NY: Cold Spring Harbor Laboratory, 165-81.

Smith, Darlene Brannigan (1990), "The Economics of Information: An Empirical Approach to Nelson's Search-Experience Framework," Journal of Public Policy \& Marketing, 9, 111-28.

Smith, Robert E, and William R. Swinyard (1982), "Information Response Models: An Integrated Approach," Journal of Marketing, 46 (Winter), 81-93.

Starek, Roscoe B., III (1993), "Ross Starek's Wish List: Or, a Call for Extrinsic Evidence," prepared remarks made at the Marketing and Public Policy Conference, June, East Lansing, MI.

Steiger, Janet D. (1994), "Keynote Address," presented at Marketing and Public Policy Conference, May, Washington, DC,

Stewart, David W. (1995), "Deception, Materiality, and Survey Research: Some Lessons from Kraft," Journal of Public Policy \& Marketing, 14 (Spring), 15-28, and Ingrid M. Martin (1994), "Intended and Unintended Consequences of Warning Messages: A Review and Synthesis of Empirical Research," Journal of Public Policy \& Marketing, 13 (Spring), 1-19. 
Stouffer Foods Corporation (1994), Commission Decision, FTC Docket No. 9250, slip opinion, October 4, 1-21.

Sudman, Seymour (1995), "When Experts Disagree: Comments on the Articles by Jacoby and Szybillo and Stewart," Journal of Public Policy \& Marketing, 14 (Spring), 29-34.

Szykman, Lisa R., Paul N. Bloom, and Alan S. Levy (1997), "A Proposed Model of the Use of Package Claims and Nutrition Labels," Journal of Public Policy \& Marketing, 16 (Fall), 228-41.

Tanner, John F., Jr., James B. Hunt, and David E. Eppright (1991), "The Protection Motivation Model: A Normative Model of Fear Appeals," Journal of Marketing, 55 (July), 36-45.

Thompson Medical Company Inc. (1984), 104 FTC, 648-844.

Tversky, Amos and Daniel Kahneman (1981), "The Framing of Decisions and the Psychology of Choice," Science, January, 453-58.

Viswanathan, Madhubalan (1994), "The Influence of Summary Information on Usage of Nutrition Information," Journal of Public Policy \& Marketing, 13 (Spring), 48-60.

Wilkie, William L. (1985), "Affirmative Disclosure at the FTC: Objectives for the Remedy and Outcome of Past Orders," Journal of Public Policy \& Marketing, 4, 91-111.

(1997), "Developing Research on Public Policy and Marketing," Journal of Public Policy \& Marketing, 16 (Spring), 132-36.

and David M. Gardner (1974), "The Role of Marketing Research in Public Policy Decision Making," Journal of Marketing, 38 (January), 38-47.

-, Dennis L. McNeil, and Michael B. Mazis (1984), "Marketing's 'Scarlet Letter': The Theory and Practice of Corrective Advertising," Journal of Marketing, 48 (Spring), 11-31.

and Elizabeth S. Moore (1999), "Marketing's Contributions to Society," Journal of Marketing, 63 (Special Issue), 198-218.

Zuckerman, Mary Ellen (1990), "The Federal Trade Commission in Historical Perspective: The First Fifty Years," in Marketing and Advertising Regulation: The Federal Trade Commission in the 1990s, Patrick E. Murphy and William L. Wilkie, eds. Notre Dame, IN: University of Notre Dame Press, 169-202. 